\title{
WORK MOTIVATION PECULIARITIES OF EMPLOYEES FROM VARIOUS INDUSTRIES IN LATVIA
}

\section{SUMMARY}

Introduction. As a result of theory and empiric researches, in this article the authors analyse peculiarities of work motivation in companies of educational, service sphere, national armed forces, finance fields according to various motivation theory positions.

Aim of the Study. To comparatively analyse the empirically acquired data on peculiarities of work motivation in companies of various fields.

Materials and Methods. The empiric results of the research have been acquired through questionnaires and interviews at companies, data processing and analysis used descriptive methods of statistics: distribution of frequency, calculation of the average indicators and ranging.

Results. Work motivation peculiarities in the years of 2007, 2008, and 2009 are compared in the article focusing on influence of the economic crisis on work motivation. The authors of the article upon summarising the acquired results address the importance of solving the issues of internal communication in relation to work motivation.

Conclusions. The acquired results show differences and common traits of employees' work motivation at companies of various fields.

Key words: motivation theory, work motivation, internal communication, motivating and demotivating factors

\section{INTRODUCTION}

When analysing motivation theories, it can be stated that although they have emerged in various time periods and various social-economic circumstances, they are significant also today. While analysing and studying development of business and its relation to employees' motivation, it is impossible to explain everything from the point of view of a single theory. Thus theories of contents (Maslow, 1954; Alderfer, 1980; House, Wigdor, 1976; McClelland, 1961) make an indepth analysis in human needs, thus these theories help a manager to understand how employees' needs can be respected, satisfied at the place of work; process theories (Vroom, 1976; Adams, 1965; Locke, 1976, 2000) focus on human thinking processes and influence of the work environment on work motivation, this in turn helps to understand how and why a certain behaviour emerges, how to direct and maintain it.

\section{AIM OF THE STUDY}

To comparatively analyse the empirically acquired data on peculiarities of work motivation in companies of various fields.

\section{MATERIALS AND METHODS}

In 2007 and 2008, students of various bachelor's degree, professional and master study programmes and lecturers of the RTTEMA in cooperation of organisations carried out researches in Latvian companies and institutions on possibilities to increase employees' work motivation, and 
the acquired findings were included in study, master papers and result analyses of applied studies (Dzirkale, 2008; Gorbunova, 2008; Zuntnere-Fomina, 2008; Gaile, Lasmane, 2008; Kurzemniece, Lasmane, 2008; Paškēviča, Lasmane, 2008; Legzdiṇa, 2009; Butkus, Sautiņš, 2009; Rutka, Sautiňš, 2009). The papers analysed data on factors that affect employees' work motivation and employees' satisfaction with work in the spheres that the respective researchers were interested in. In this research, the factors influencing the employees' work motivation of various industries were summarised and ranged; all data was summarised in two tables (see Tables 1 and 2).

Table 1. Factors that influence the employees' work motivation in various companies and institutions

\begin{tabular}{|l|c|c|c|c|c|}
\hline \multicolumn{1}{|c|}{ Factors } & NBS & $\begin{array}{c}\text { State } \\
\text { Administration } \\
\text { System }\end{array}$ & Trade & Services & Finances \\
\hline $\begin{array}{l}\text { Positive evaluation from the management and } \\
\text { colleagues }\end{array}$ & 7 & 6 & 8 & 9 & 5 \\
\hline Opportunity to be creative & 10 & 9 & 9 & 3 & 8 \\
\hline $\begin{array}{l}\text { Participation in planning work at the institution, } \\
\text { taking decisions }\end{array}$ & 8 & 7 & 7 & 8 & 10 \\
\hline Support from the management and colleagues & - & 2 & - & 7 & 6 \\
\hline Psychological work environment & 2 & 1 & 1 & 1 & \\
\hline $\begin{array}{l}\text { Opportunity to use one's special abilities at work } \\
\text { (career development) }\end{array}$ & 6 & 8 & 6 & 5 & 2 \\
\hline Respect of the manager towards results & 3 & 5 & 10 & - & 7 \\
\hline Autonomy when performing the duties & 9 & 10 & 2 & 6 & 9 \\
\hline Salary and material stimuli & 4 & 3 & 3 & 2 & 1 \\
\hline Work environment (physical, ergonomic) & 1 & 4 & 5 & 4 & 3 \\
\hline Convenient work schedule & 5 & 11 & 4 & 10 & 4 \\
\hline
\end{tabular}

Table 2. Factors that influence the employees'work motivation in educational institutions

\begin{tabular}{|l|c|c|c|c|}
\hline \multicolumn{1}{|c|}{ Factors } & $\begin{array}{c}\text { PII } \\
\text { teachers (of } \\
\text { kindergartens) }\end{array}$ & $\begin{array}{c}\text { Teachers of } \\
\text { basketball } \\
\text { schools }\end{array}$ & $\begin{array}{c}\text { Teachers of } \\
\text { professional } \\
\text { education } \\
\text { institutions }\end{array}$ & $\begin{array}{c}\text { PII technical } \\
\text { workers }\end{array}$ \\
\hline $\begin{array}{l}\text { Positive evaluation from the management and } \\
\text { colleagues }\end{array}$ & 1 & 2 & 3 & 6 \\
\hline Opportunity to be creative & 2 & 7 & 9 & - \\
\hline $\begin{array}{l}\text { Participation in planning work at the institution, } \\
\text { taking decisions }\end{array}$ & 3 & 9 & 8 & 9 \\
\hline Support from the management and colleagues & 4 & 8 & 2 & 5 \\
\hline Psychological work environment & 5 & 5 & 1 & 4 \\
\hline $\begin{array}{l}\text { Opportunity to use one's special abilities at work } \\
\text { (career development) }\end{array}$ & 6 & 1 & 10 & - \\
\hline Respect of the manager towards results & 7 & 6 & 4 & 1 \\
\hline Autonomy when performing the duties & 8 & 3 & 5 & 2 \\
\hline Salary and material stimuli (remuneration) & 10 & 4 & 7 & 7 \\
\hline Work environment (physical, ergonomic) & 9 & 10 & 6 & 8 \\
\hline Convenient work schedule & - & - & - & 3 \\
\hline
\end{tabular}


Results of the research confirm findings of earlier researches that a strong management is a significant and influential means for motivating employees. It important that employees understand that not only the company future depends on the management, but also the options of their development and career, as well as work environment and quality (Armstrong, Stephens, 2005). Often, the amount of the salary as the most important motivator is accepted as the unquestionable conclusion, but the practice shows that even if a person has a very good salary and various other advantages and privileges, he can be dissatisfied with his work, and can seek options to settle at a different job just because the psychological environment in the work collective is too unfavourable with may mutual conflicts, "unhealthy" mutual relations, unclear division of job duties with all the resultant consequences.

Researches performed in Europe and the USA (Schein, 2002; Cong, Borg, Spector, 2004; Nieto, 2006) confirm the theory assumptions that involvement of employees in solving the company problem issues positively affects the work results. This is ensured by regular and efficient communication. Involvement of USA employees and participation in associations indicate that $65 \%$ of business persons who were interviewed are of the opinion that it is the active involvement of employees in all practical activities of the organisation that ensures high competitiveness. This was confirmed also by employees of these companies (Taurina, 2007). In another research, 31\% of the interviewed employees expressed opinion: they are not certain that the company manager would devote his time to explain changes in the company; however, $20 \%$ of employees have no clear reply to this question. Each employee finds the explanation by the management about changes expected in the company to be important, but a half of employees are sure that the manager will timely explain the changes to his team (a research by Applied Information Service (Lietišksās informācijas dienests, 2008).

Interpreting the results of researches should be related to the term MATTRESS used in English and it can be perceived as an abbreviation where each letter signifies some aspect of motivating an individual:

- "Money". These people strive for money with the aim to acquire a larger capital; therefore they find it important to get material remuneration.

- "Advancement". These people wish to move up the career. Work very hard.

- "Training". These employees wish to acquire new professional competencies. Often, this is characteristics of young people or of them who have just begun to work in an area.

- "Travel and recreation". This is characteristics of people who wish to gain joy from travel opportunities and social activities.

- "Relationships". These employees' life is related to other people. They like to talk, dislike being alone.

- "Education". They appreciate the possibility to acquire academic education.

- "Security". They wish a secure and stable life. They are afraid of losing the job. Sometimes these are very loyal employees with low income.

- "Stillness". They search for the internal peace in life. They try to make the world a better place and are of the opinion that by their work they are doing it. They try not to think of work at home (Nieto, 2006).

The conclusion that necessities can be satisfied with remuneration by giving a person what he finds to be valuable is very significant for the issue to be researched in the situational context. However, the notion "value" is understood differently by each person and respectively, 
the evaluation of remuneration differs (Cong, Borg, Spector, 2004), moreover, as it is known, the system of values changes during the life-time, it is affected by a whole spectrum of external and internal factors. This opinion widens the view at the essence of remuneration that is specified also by the opinion the system of remuneration regulates and controls the relation between productivity and profit, and employees' satisfaction with work (Ešenvalde, 2007; McCausland, Pouliakas, Theodossiou, 2005).

Comparing factors influencing employees' work motivation in companies and institutions of various areas, it can be seen that employees working in different areas have different evaluation of it (see Tables 1 and 2). This obviously is affected by the specifics of the employment area, as well as motivation for choosing the profession. This statement is especially pronounced by motivation of workers at the financial sphere that differs from the motivation of employees of other spheres covered by the researches. Still the factors motivating employees in this sphere are quite close to the employees working in the service sphere.

Workers of all spheres find the psychological and physical environment very important. Which is also understandable: to work qualitatively, a person needs to feel secure and comfortable. The research shows that pedagogues in comparison to employees of other spheres find the physical and ergonomic work environment less important. This is related to the specifics of their work, namely, a pedagogue himself is responsible for securing a comfortable work environment for pupils and by creating the work environment for pupils he forms environment for him, of course, to feel as comfortable as possible. Likewise, however, the significance of a manager for providing the pedagogue with a comfortable work environment is not inessential.

As can be seen in Table 2, factors influencing work motivation of technical employees involved in the researches differ from the factors influencing pedagogues' work motivation. Some of the offered factors are even insignificant. This can be explained by the different character of the work.

Having compared the factors influencing work motivation of employees at various education institutions, it can be seen that there are no big differences, only pedagogues from basketball schools finds those factors important that relate to awareness of oneself as an important person, even possibilities to feel certain supremacy. This is perfectly understandable because competition is inherent to sports and for everyone it is important to be the first, the best. Thereby a fact could be explained that for pedagogues of basketball schools the salary is more important than for other pedagogues because it can be seen as an acknowledgement that a person's achievements are higher in comparison to colleagues. In turn, teachers of preschool educational institutions should be aware and demonstrate their creativity to others. For these pedagogues, the option to engage in planning the work of the institution and decision making is likewise comparatively more important. This could be related, on the one hand, with the style of work of PII managers who deny employees this option (researches show that the majority of PII managers have a prevailing style of authoritarian management); on the other hand, in most cases, PII personnel is small in numbers and teachers are not only informed about all decisions of the management but they also are directly or indirectly involved in their adoption and explanation to parents. Pedagogues from the other educational institutions, on the contrary, not always feel the necessity to become involved in planning development of the institution, as well as they do not have to explain the decisions related to development of the institution as often as the preschool teachers must.

Employees of all kinds of education institutions have a characteristic need of a favourable 
psychological environment at the place of work. This is observable not only by having indicated the psychological working environment as being important, but also by having stressed the positive evaluation by the management and colleagues, manager's respect, support from the manager and colleagues. Simultaneously with this factor, domination could be related also to the fact that the pedagogical work is a collective work, namely, one even the best pedagogue alone cannot and is not able to qualitatively fulfil his functions without a direct and indirect support from colleagues. A congenial psychological environment as a significant factor affecting work motivation is market by representatives of all industries involved in the research.

The issue of the congenial psychological environment is related to a productive internal communication that is usually expressed as multiform exchange of information in a company. Without the effective internal communication employees lack understanding of company targets and tasks, their place in achieving the targets and they lack a genuine motivation for work.

A large part of company managers and employees see mutual exchange of information as one of the most important fields that should be improved in Latvian companies (Iekšējās komunikācijas, 2009). Motivation is one target of internal communication that is specified in tasks: to inform employees about the relation of their work and their individual wellbeing to the company development; to gain employees' trust and cause the feeling that the employees are very important for the company development, to inform about career development opportunities, thus decreasing personnel movement, to satisfy employees' wishes to receive more information about targets of company activities, results, changes in the management, management work, personnel changes in various levels, to get involved in decision making, express objections and evaluate a manager's work (Tūla, Jari, Tūliki, 2005; Tracy, Myers, Scott, 2006). Internal communication is very topical during changes because the changes cannot take place without employees' participation, and employees can fully participate in changes only if they have enough information. Researches lead to the conclusion that communication between administration and employees is a factor that facilitates events and should be regarded as influential means for ensuring changes successfully (Ešenvalde, 2007).

International public relations agency "Consensus PR” has summarised most typical mistakes of internal communication:

- manager's opinion that subordinates get sufficient information about the plans, vision, current events of the company and the like;

- viewpoint that audit of internal communication is expensive and does not pay back (effective internal communication, however, can bring profit because employees who are better aware of their tasks and benefits, will work better);

- hiding information from employees and fearing that its disclosure would have negative consequences;

- delayed provision of information, when somebody else, for example, the dismissed employee has already told his version about what happened and turned the whole personnel against the management; thus rumour is circulated in the company instead of true information;

- choice of incorrect means of communication, for example, by sending management notices by e-mail, although most employees usually do not read e-mails, instead of placing notices on notification board, for example, or issuing a company newsletter;

- choice of inappropriate management style when running meetings, giving tasks (Consensus PR, 2007). 


\section{RESULTS}

The research in 30 organisations of Latvia showed (see Picture 1) that most popular means of communications is indirect communication: internet $23 \%$, written notices $18 \%$. Whereas Picture No 2 shows that for employees, the most important in communication is mutual emotions and being personal that is expressed in attitude towards the received information, for in this case the person who perceives the information not only hears but also feels the information as provided by the sender, he feels the attitude of the person who provides the information towards the information and the person who perceives it. By using direct means of providing information, managers could be more certain that employees have definitely received the information, have got acquainted with it and understood because in case of direct communication the listener, thus the employee feels sure about the employer's trust and better understands the targets of the organisation.

In a situation when a company undergoes changes, management of employees' motivation is important (Bērziņš, Nēbels, 2006). For example, in researching the situation of change of Hansabanka brand (2009), it was concluded that $85 \%$ of employees were informed about the planned changes, that is, company management, by using various channels, both direct (the manager's oral announcement) and indirect (had successfully sent information about changes through internal computer network - intranet). $87 \%$ of employees of all age groups confirmed that everyone knew the real cause why the company name is changed and employees were informed about the company aim, vision.

When studying company competitiveness during economic recession, it has been concluded that $69 \%$ of employees are sure that company management is actively working at increasing company competitiveness and efficiency. This is quite a good indicator. Furthermore in $76 \%$ of cases, employees are sure that the company management is interested in their investment, as well as in ideas for intensification of efficiency and competitiveness (Research by the Applied Information Service, 2009).

In the context of work motivation, employees' satisfaction with work is important.Apart of authors in explanation of satisfaction with work stress differentiation, namely, personnel seeks various benefits at work that are related with various aspects in their work (Job Satisfaction and Plans for the Future http://www.leeds.ac.uk/ educol/ncihe/r4_214.htm). For example, niche finders choose more attractive place of work in private business; subject specialists value the opportunity to work in compliance with their interests in a stimulating and intellectual environment; new professionals search dynamism and

\section{Picture 1. Types of internal communication in companies (Butkus, Sautiņš, 2009)}

Types of transferring the IC

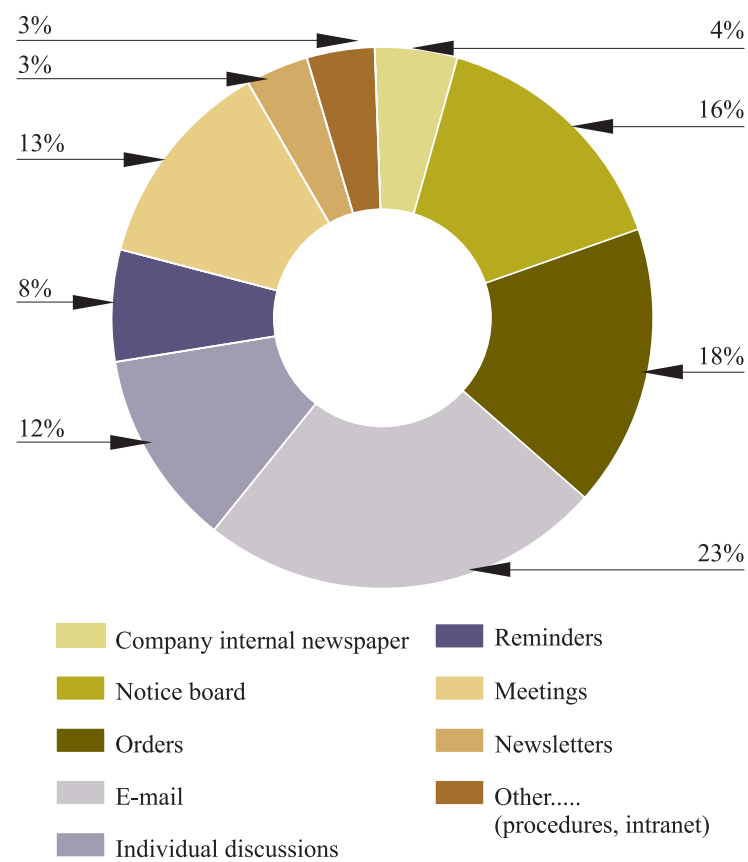




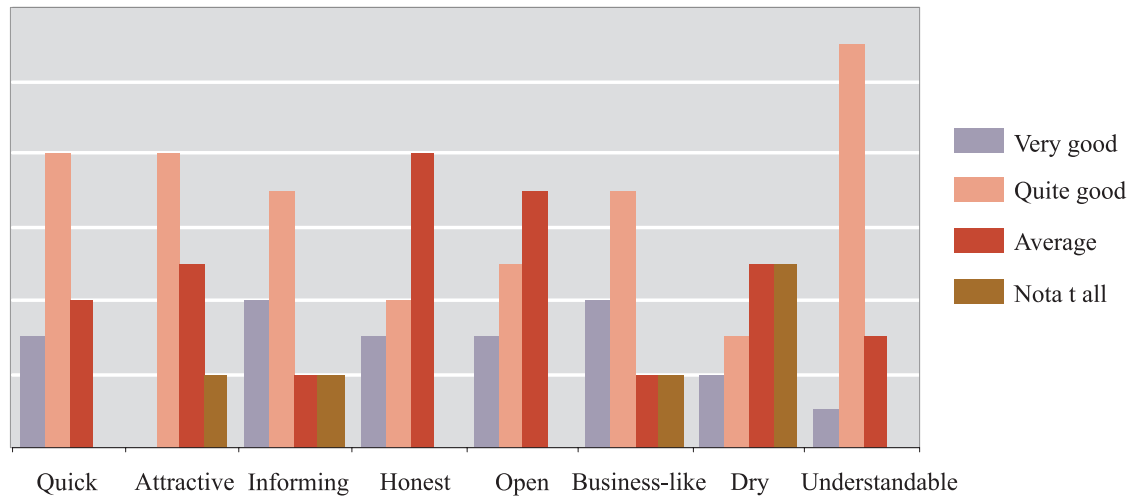

autonomy, and payment options. Causes for dissatisfaction with work usually are lack of several conditions: insufficiency of opportunities for development (career formation), appreciation, corresponding remuneration, resources; these may cause fear and frustration (Job Satisfaction and Plans for the Future http://www.leeds.ac.uk/educol/ncihe/r4_214.htm); moreover, for employees of various categories combinations of these factors differ.

Simultaneously with factors affecting employees' work motivation, those factors that relate to employees' dissatisfaction with work were found out during the research. Having reviewed factors that negatively affect work motivation, it can be seen that employees have named factors that are indicated as affecting motivation, but according to the employees have not been provided by the management to the extent that they would be satisfied with it. If significance of a factor facilitating motivation for employees of various areas was different, then reason for dissatisfaction with work did not especially differ. Obviously managers of institutions and companies in Latvia irrespective of the company activity field choose similar management strategy.

Factors that negatively affect work motivation:

1. Remuneration that does not correspond to the invested work.

2. Inadequate ergonomic conditions in the work environment.

3. Lack of information (about organisation plans, aims, management decisions and the like).

4. Limited career development possibilities.

5. Management style inappropriate for the situation.

6. Negative criticism by the manager and colleagues.

7. Mutual competition between employees and conflicts caused by it.

8. Large amount of work / overwork.

9. Stress.

10. Routine.

11. Excessive control by the manager.

Evaluating the situation in Latvia, one should recognize that so far when thinking about improving employees' motivation managers have more often turned to issues of salary because that provided an immediate result, but they drew little attention to other aspects.

Direct manager's influence on employees' motivation is huge; this is proved by employees' satisfaction researches abroad and in Latvia (Ešenvalde, 2007). Most important observed regularity: 
if an employee is dissatisfied with the direct manager, then this influences his overall satisfaction with other aspects of work, in turn, if the employee is satisfied with the manager, he is satisfied also with other aspects of work, including salary. This means that the direct manager causes the largest influence on employees' satisfaction, loyalty and motivation. Therefore in situations of crisis company management must especially carefully evaluate how lower-level manager succeed in managing employees subjected to them whose structural unit employees are dissatisfied and cause losses to the company.

As Latvia faces economic crisis and all around funds are economised; in order to keep business going not only in state institutions but also in the private sector, companies have started to economise on the account of the number of employees. Many institutions undergo optimisation, restructuring, employee dismissal. To find out whether in this situation factors influencing employees' work motivation are changed, data on the structure of employees' work motivation were repeatedly collected. As seen in Table No 3, the data acquired in the first half of 2009 differ from data acquired in 2007 and 2008 (see Pictures 1 and 2). Pedagogues mention remuneration as one of very significant motivators, as well as a new factor appears that has been mentioned very rarely - prestige of the profession.

These changes in employee's work motivation should be directly related to changes of economic situation in the country.

The conclusion that necessities can be satisfied with remuneration by giving a person what he finds to be valuable is very significant for the issue to be researched in the situational context. However, each person understands the notion "value" differently and respectively, the evaluation of remuneration differs (Cong, Borg, Spector, 2004); moreover, as it is known, the system of values is changing during the life-time, it is affected by a whole spectrum of external and internal factors. This opinion widens the view at the essence of remuneration that is specified also by the opinion that the system of remuneration regulates and controls the relation between productivity and profit, and employees' satisfaction with work (Solberg, Diener, Wirtz, Lucas, Oishi, 2002; McCausland, Pouliakas, Theodossiou, 2005; Ešenvalde, 2007).

Table 3. Factors that influence the employees'work motivation in educational institutions (Spring, 2009)

\begin{tabular}{|l|c|c|}
\hline \multicolumn{1}{|c|}{ Factors } & $\begin{array}{c}\text { Teachers of } \\
\text { kindergartens }\end{array}$ & $\begin{array}{c}\text { Teachers of general } \\
\text { education schools }\end{array}$ \\
\hline Positive evaluation from the management and colleagues & 11 & 7 \\
\hline Opportunity to be creative & 1 & 3 \\
\hline Participation in planning work at the institution, taking decisions & 12 & 12 \\
\hline Support from the management and colleagues & 2 & 4 \\
\hline Psychological work environment & 7 & 7 \\
\hline Opportunity to use one's special abilities at work (career development) & 5 & 5 \\
\hline Respect of the manager towards results & 8 & 2 \\
\hline Autonomy when performing the duties & 9 & 10 \\
\hline Salary and material stimuli (remuneration) & 4 & 1 \\
\hline Work environment (physical, ergonomic) & 10 & 9 \\
\hline Convenient work schedule & 3 & 11 \\
\hline Prestige of the profession & 6 & 6 \\
\hline
\end{tabular}


Factors influencing employees' motivation at finance service area in comparison to 2007 and 2008 have not significantly changed (see Picture No 3).

Picture 3. Factors motivating employees in companies of finance services (Rutka, Sautiņš, 2009)

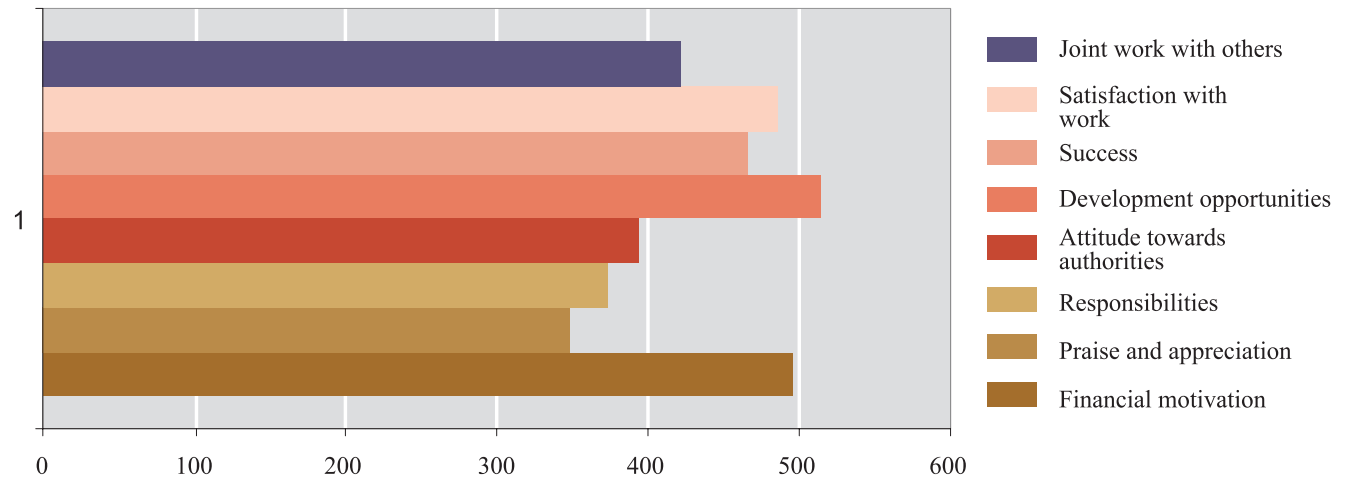

During the crisis, it is necessary to draw a special attention to non-material stimulation because the material stimulation lacks sufficient means. As considered by manager of a representative office in Latvia on international company FranklinCovey, Mārtiņš Martinsons, material stimuli provides a very short-term effect (Матафонова, 2009). The material factor soon (in 3-6 months) turns from a "gift" to a "right" to receive compensation for one's work (Казарин, 2009), a part of employees start considering it as self-evident and if they do not receive it - start demanding.

The system for motivating employees should be changed in line with the present situation. In the time of changes, one of most powerful employee motivators could be feeling of security and stability.

Researches in companies in Latvia show that a part of managers has understood that and work correspondingly, but another part uses employees' fear from dismissal as motivator. If not long ago employees were motivated by remuneration: premiums, bonuses, training and other benefits, then now, it can be often heard that employees are motivated by dismissal. However, it should be indicated that fear motivates people to survive, not to reach a company's targets. This approach may possibly provide a short-term result, but in the long term, this will lead the company to losses. In this situation, the employee will do exactly as much as not have him dismissed and as soon he feels the control relaxing, he will work with lesser results. Instead of threats, company management should turn to creation of a feeling of security and stability. Managers must undertake the role of a leader - must ensure direction of the company, maintain the employees' optimism, must stop telling employees about the complicated present economic situation, but they should involve employees in development of company vision. If the state is unstable, then a person must feel stable in the company, only then the employee will turn to reaching the company targets. That is why communication chain is necessary and efficient in each company, it ensures healthy business environment in a company and does not create psychological tension among employees as a result the company can act progressively (Taurina, 2007).

For illustrating the above, a situation in two companies of Latvia: in company A (service industry) (2009), it was revealed that employees in this company are in doubt about their future because - about chances to keep the job in the following months: $50 \%$ of respondents were 
completely sure, $40 \%$ of respondents were not so sure, and $10 \%$ of respondents were not sure at all. In company B (public utility industry) (2009), it was revealed that employees have a positive attitude towards all processes taking place in the company, the system of remuneration and motivation is highly appreciated.

\section{CONCLUSIONS}

The remuneration is a significant but not the dominating factor for satisfaction with work and thus also work motivating factor; the most significant remuneration factor is for employees who work in the financial sector, for employees who work in education sector it is comparatively less important.

A significant motivation factor is management quality and psychological work environment.

In the aspect of work motivation, the quality of internal communication, involvement of employees in solving company development issues, ensuring reciprocal link as consultative process lessening employees' stress, ensuring feeling that they can control the situation, is important.

Work motivation is negatively affected mainly by remuneration that does not correspond to the investment, inappropriate ergonomic environment, lack of information about development of the organisation.

In the situation of economic crisis, the significance of remuneration factor, prestige of the profession (for employees of the educational sphere) and safety and stability factor increases for work motivation.

\section{REFERENCES}

1. Adams, J. S. (1965) Inequity in Social Exchange. Adv. Exp. Social Psychology, No 62, p. 335-343.

2. Alderfer, C. P. (1980) The Methodology of Organizational Diagnosis. Professional Psychology, No 11, p. 459-468.

3. Armstrong, M., Stephens, T. A. (2005) A Handbook of Management and Leadership. A Guide to Managing for Results. London: Kogan Page, 242 p.

4. Bērziņš, I., Nēbels, K. P. (2006) Cilvēku, zīmolu, mediju un kultūras menedžments [Management of People, Brands, Media and Culture]. Rīga: Jāņa Rozes apgāds, 239 lpp. (in Latvian).

5. Cong, L., Borg, I., Spector, P. E. (2004) Measurement Equivalence of the German Job Satisfaction Survey Used in a Multinational Organization, Implications of Schwarz's Culture Model. Journal of Applied Psyhology, No 89, p. 1070-1082.

6. Consensus PR. 6 iekšejjās komunikācijas tipiskākās kļūdas [Most Typical Mistakes of Internal Communication 6]. (07.06.2007.) 7guru.lv/search/?search-text=mārketingā (06.06.2009.) (in Latvian).

7. Ešenvalde, I. (2007) Pārmaiņu vadība [Management of Changes]. Rīga: Jāṇa Rozes apgāds, 264 lpp. (in Latvian).

8. House, R., Wigdor, L. A. (1976) Herzbergs Dual Factor Theory of Job Satisfaction and Motivation. Personall Psychology, Vol. 20, p. 369-389.

9. Iekšèjās komunikācijas (2009) [Internal Communication]. SIA "Latvijas standarts" 5.3. www.lvs.lv (11.05.2009.) (in Latvian).

10. Job Satisfaction and Plans for the Future. http://www.leeds.ac.uk/educol/ncihe/r4 214.htm (12.05.2009).

11. Lietišķās informācijas dienesta pétījums (2009) [Research by the Applied Information Service]. (08.06.2009.) www.lid.lv.20089 (10.06.2009.) (in Latvian). 
12. Locke, E. A. (1976) The Nature of Causes and Job Satisfaction. In: Dunette, M. D. (Eds.) Handbook of Industrial and Organizational Psychology. Chicago: Rand McVally, p. 1297-1349.

13. Locke, E. A. (2000) The Blackwell Handbook of Principles of Organizational Behavior. Blackwell Bussines, p. 445.

14. Maslow, A. (1954) Motivation and Personality. New York: Harper, p. 236.

15. McCausland, W. D., Pouliakas, K., Theodossiou, I. (2005) Some are Punished and Some are Rewarded. A Study of the Impact of Performance Pay on Job Satisfaction. International Journal of Manpower. Vol. 26, No 7/8, p. 636-659.

16. McClelland, D. C. (1961) Methods of Measuring Human Motivation. In: Atkinson, J. W. (Eds.) The Achieving Society. New Jersey: D. Van Nostrand, p. 41-43.

17. Nieto, M. L. (2006) An Introduction to Human Resource Management. New York: Palgrave Macmillan, $284 \mathrm{p}$.

18. Schein, E. H. (2002) Modells and Tools for Stability and Change in Human Systems. Reflections. Winter, Vol. 4, No, p. 34-46.

19. Solberg, E. C., Diener, E., Wirtz, D., Lucas, R. E., Oishi, S. (2002) Wanting, Having and Satisfaction: Examining the Role of Desire Discrepancies in Satisfaction with Income. Journal of Personality and Social Psychology, Vol. 83, No 3, p. 725-734.

20. Tauriņa, Ž. (2007) Komunikācija, konsultācijas un iesaistī̌sana [Communication, Consultations and Involvement]. Biznesa psihologija, 32. lpp. (in Latvian).

21. Tracy, S. J., Myers, K. K., Scott, C. W. (2006) Cracking Jokes and Crafting Selves: Sensemaking and Identity Management Among Human Service Workers. Communication Monographs, No 73, p. 283308.

22. Tūla, L., Jari, R., Tūliki, J. (2005) Mentoringa daudzās sejas [The Many Faces of Mentoring]. Rīga: Applied Information Service, 198 p. (in Latvian).

23. Vroom, V. H. (1976) Work and Motivation. New York: John Willy \& Son Inc., p. 175-184.

24. Казарин, М. (2009) Коучинг в условиях финансового кризиса [Coaching in Conditions of Financial Crisis]. http://www.kazarin.clan.su (07.06.2009.) (in Russian).

25. Матафонова, М. (2009) Поговори со мной, начальник [Speak to Me, Manager]. Бизнес\&Балтия, № 3 (3629) Wednesday, 21.01.2009., p. 2 (in Russian).

Non-published material, researches:

1. Butkus, D., Sautiņš, N. (2009) Organizācijas iekšējās komunikācijas efektivitāte un kritēriji. Studiju darbs [Efficiency and Criteria of Internal Communication in Organisation. Research paper]. Rīga, 5., 7., 16.-18., 20.-23. lpp. (in Latvian).

2. Dzirkale, I. (2008) Profesionālās izglītības iestā̌̌u pedagogu profesijas motivācijas veicināšana. Magistra darbs [Facilitation of Motivation of Pedagogues' Profession in Professional Educational Insitutions. MA Paper]. Rīga, 49.-63. lpp. (in Latvian).

3. Gaile, E., Lasmane,A. (2008) Vad̄̄bas lēmumu efektivitāte un psihologiskā sasprindzinājuma mazināšana Hansabankas zìmola maiņas procesā. Lietišķais pētījums [Efficiency of Management Decisions and Decrease of Psychological Tension in the Process of Changing Hansabanka Brand. Applied Research]. Rìga, 16.-19., 28.-32. lpp. (in Latvian).

4. Gorbunova, K. (2008) Pirmsskolas izglītības iestādes vadītāja darbība skolotāju darba motivācijas pilnveidošanai. Maǵistra darbs [Activity of a Pre-School Educational Insitution Manager for 
Improvement of Teachers' Work Motivation. MA Paper]. Rīga, 60.-83. lpp. (in Latvian).

5. Kurzemniece, E., Lasmane, A. (2008) Darbinieku apmierinātības nozīme uzņēmuma tēla veidošanā. Lietišksais pētijjums [Significance of Employees' Satisfaction in Formation of the Company Image. Applied research]. Rīga, 20.-35. 1pp. (in Latvian).

6. Legzdiña, S. (2009) Izglītības iestādes vadības iespējas pedagogu darba motivāaijas paaugstināšanāa. Maǵistra darbs [Management Options in Educational Institution for Increasing Pedagogues' Work Motivation. MA Paper]. Rīga, 44.-52. lpp. (in Latvian).

7. Paškēviča, Z., Lasmane, A. (2008) Darbinieku apmierinātības ar darbu un vadības stila saistības izpēte uzñēmumā. Lietišşais pētījums [Study of Employees' Satisfaction with Work and Relation of the Management Style. Applied Research]. Rīga, 14., 23. lpp. (in Latvian).

8. Rutka, J., Sautiņš, N. (2009) Personāla motivēšanas sistēma uzņēmumā „B”. Studiju darbs [A System of Motivating the Personnel in Company "B”. Research Paper]. Rīga, 3.-4., 24.-29. 1pp. (in Latvian).

9. Zuntnere-Fomina, K. (2008) Vadītāja darbība pedagogu motivācijas pilnveidē basketbola skolās. Maǵistra darbs [Manager's Activity in Improvement of Pedagogues' Motivation in Basketball Schools. MA Paper]. Rīga, 48.-61. lpp. (in Latvian).

Associate professor Dr. psych. Anita Lasmane

Riga Teacher Training and Educational Management Academy

Address: 18 Dāliju Str., Rīga

Phone: +371 29115177

E-mail: anita.lasmane@rpiva.lv

Assistant Professor Dr. paed. Iveta Kāposta

Riga Teacher Training and Educational Management Academy

Address: Imantas 7. līnija 1, Rīga, LV-1083

Phone: +371 29132756

E-mail: iveta.kaposta@rpiva.lv

Assistant profesor Dr. paed. Nils Sautiņš

Riga Teacher Training and Educational Management Academy

Address: 26 Dammes Str. 71, Rīga

Phone: +37128460114

E-mail: nils.sautins@rpiva.lv 